\title{
Retirement migration and transnational grandparental support: a Spanish case study
}

\author{
MARION REPETTI AND TONI CALASANTI \\ Virginia Tech, Sociology, Blacksburg, Virginia, USA \\ marion.repetti@gmail.com (corresponding author) \\ toni@vt.edu
}

\begin{abstract}
People who migrate in retirement often do so to join younger generations who have already migrated, and to help with grandchildren. But what about those retirees who migrate away from their families? Do they still provide grandparental support? To address this question, we examine retirement migrants who reside permanently in their new country, Spain. We find that they are aware of grandparental support expectations, and that their migration decision sometimes creates conflict with their offspring. At the same time, these retirement migrants reshape the meaning of grandparental support. Care considerations influence their destination and housing choices, and they continue to provide care. They feel that their familial relationships are now of a higher quality, despite the distance. At the same time, gender still emerges as a key dimension of grandparental support. The grandparenting of these retirement migrants challenges facile depictions of their motivations and of the equation of quantity and quality of contacts.
\end{abstract}

Keywords GENDER, GRANDPARENTAL SUPPORT, RETIREMENT MIGRATION, SPAIN, TRANSNATIONAL GRANDPARENTING

International migration has intensified and diversified over the last 70 years (Castles et al. 2014; Goodson and Grzymala-Kazlowska 2017). Most people migrate in search of safer places and more opportunities for paid work. When they retire, some return to the home countries they had left years before for employment reasons; and others migrate after retirement to a new country (Torres 2012), sometimes to join and support children and grandchildren who had moved there (King et al. 2014; Nedelcu 2009). Others, particularly citizens of wealthier countries - often from the Global North move to poorer countries - often in the Global South - where they find communities of similar retirees (Oliver 2008). Our focus in this article is on this last group.

In the absence of family or homeland motivations, these retirement migrants move for reasons such as enjoying a more congenial 'lifestyle' (Benson and O'Reilly 2009; Oliver 2008) in a pleasanter climate or having greater economic security through living in a country with a lower cost of living (Hayes 2015; Huete et al. 2013; Repetti et al. 
2018). Some of these migrants move on a seasonal basis (King et al. 1998: 95), essentially having a second home, while others establish permanent residence in the new country (Longino and Marshall 1990). Being permanent residents does not mean that they cut all ties with their previous country. Like other retirement migrants (King et al. 2014; Nedelcu 2009), many travel regularly from their new place of living to their home country (Castles et al. 2014; Longino and Marshall 1990).

This type of retirement migration raises the question of how people deal with family support transnationally, while trying to improve their quality of life, particularly when they are trying to escape economic insecurity (Repetti et al. 2018). This group stands apart from those who move to join their families in new countries, which is interesting in the context of evidence that, in the Global North, retirees are increasingly being called upon to provide family support, particularly in caring for grandchildren (Attias-Donfut 2008; Glaser et al. 2018; Timonen and Arber 2012). A highly competitive and unstable labour market, with increasing numbers of mothers in work, leads to a greater need for childcare. While state welfare policies can complement childcare provision or, depending on the generosity of such policies, substitute for it entirely, where there are insufficient public childcare facilities, parents are increasingly relying on grandparents for childcare. In some countries, like the UK, class inequalities have resulted in working-class parents relying quite heavily on grandparents to care for their children (Arber and Timonen 2012).

Here, we present a case study of British and Swiss retirement migrants who live permanently in Spain and whose decision to migrate was related to a search for greater economic security (Repetti et al. 2018). Our aim is to understand the extent to which such retirement migrants articulate their role of grandparental support - by which we mean childcare, keeping in touch with kin, and economic support - with their decision to move away from their grandchildren. We examine both migration decisions and life after migration. Heeding the call to examine gender influences on grandparenting, including instances of a grandparenting couple dividing the labour (Arber and Timonen 2012), our study also attends to the ways that grandmothers and grandfathers consider and experience their support role. We show that while a search to gain more economic security in retirement shaped their migration decision, these retirees also want to support their children and grandchildren transnationally. We also show that the interplay of migration and intergenerational relations for this group is complex: the decision to migrate can create intergenerational conflicts, particularly between mothers and grandmothers, who generally carry the primary responsibility for childcare. At the same time, retirement migrants also feel that family relations are now different and, from their perspective, perhaps of better quality since they left their country.

We begin with a review of the literature on grandparental support in migratory contexts, and the need to examine gender in this regard. We then note the expected role of grandparental support in European countries, in terms of enabling parents, and particularly mothers, to balance paid work and childcare; and we contrast this with assumptions about baby-boomer values concerning freedom and individualism. Based on this review, we ask, to what extent do retirement migrants engage in grandparental 
support? We also explore what role, if any, gender plays in such transnational grandparenting.

Using in-depth interview data, we show the arrangements that retirement migrants undertake to continue their grandparental support and how gender shapes this. We then discuss the assumption that retirement migrants disengage from family support and propose other ways of understanding the tensions we find between retirement migrants wishing to gain more freedom and security in retirement on the one hand and remaining supportive to their children and grandchildren on the other. We conclude that our examination of grandparenting among our participants shows possibilities for intergenerational relationships that are overlooked if we assume that proximity and frequency of contact equate with quality of grandparenting support and relationships.

\section{Grandparental support in migration contexts}

While a recent study finds that migration can weaken family support (BaykaraKrumme and Fokkema 2018) in some cases, in others, it does not disappear but is rather transformed: younger migrants who relocate to find employment provide family support across national borders in different ways (Albertini et al. 2018; Baldassar and Merla 2013; Baldassar et al. 2007; Bordone and de Valk 2016; Ducu 2018; Holmes 2010; Izuhara 2010; Purkayastha et al. 2012). In terms of specifically transnational grandparenting, there is research on grandparents caring for grandchildren in contexts where parents migrate to find better jobs, leaving their children behind (Bastia 2009). These 'zero generation' grandparents (Nedelcu 2009) - those whose children migrate - continue to support their children and grandchildren. They can provide support from a distance both through using communication technologies and/or through joining their children for specified periods to provide childcare (King et al. 2014; Nedelcu 2009, 2017; Nedelcu and Wyss 2016; Purkayastha et al. 2012). Exploring a different group, King and Lulle (2016) show that some grandmothers migrate to procure better work for themselves with a view to helping their children, grandchildren, husband and parents, as well as ensuring more economic security for themselves in their old age. The literature also highlights grandparents' abilities to travel to provide care transnationally, for months at a time, with grandmothers often at the centre of these practices (Baldassar and Merla 2013; Ducu 2018; Purkayastha et al. 2012). While such care varies according to national laws governing their rights to join their families (Ducu 2018; Gehring 2017; Zickgraf 2017), and their economic resources (Ducu 2018), across these studies, we find examples of grandparents providing vital intergenerational support in migration contexts.

There has been far less research, however, on transnational grandparenting in contexts of retirement migration. This particular form of migration would appear to present a very different grandparenting situation from those described above. Some scholars depict retirement migrants as part of a generation of privileged baby boomers (Williams and Hall 2000) who wish to be free to enjoy a time when they can focus on their own needs and interests after 'having spent years subject to the demands of the work and family routine' (Oliver 2008: 71). According to this view, retirement 
migrants would be expected to disengage from their family obligations (Ahmed 2015; Gilleard and Higgs 2005; Oliver 2008; Woodspring 2016).

This latter perspective is rooted in two assumptions. First, according to Mazzucato and Schans (2011), some migration scholars believe that family practices can be performed only when family members live in close proximity, a perspective that the evidence on transnational families challenges (Albertini et al. 2018; Arber and Timonen 2012; Baldassar and Merla 2013; Baldassar et al. 2007; Bordone and de Valk 2016; Da 2003; Ducu 2018; Holmes 2010; Izuhara 2010; King et al. 2014; Mazzucato and Schans 2011; Nedelcu 2009, 2017; Nedelcu and Wyss 2016; Purkayastha et al. 2012; Timonen and Arber 2012). Second, members of the baby-boom generation attached a high value to freedom and individualism, which led them to renegotiate their moral obligation to provide family support (Gilleard and Higgs 2005; Woodspring 2016). As a result, some authors see retirement migration as a refusal to bear the burden of care work, especially among women who traditionally perform it (Ahmed 2015; Oliver 2008). In other words, migrating might allow retirees to discard their family obligations, or at least to 'realign [their] parental responsibilities' (Oliver 2008: 93) in their attempt to live independently. Yet, Oliver's (2008) study suggests that retirees continue to support their families through kin-keeping and caregiving, and that these activities shape the organization of their daily lives. However, her research fails to produce data to illustrate these points, or the processes by which such support might occur or shape retirees' experiences.

Researchers also often overlook how gender shapes transnational grandparenting experiences generally (Arber and Timonen 2012; Timonen and Arber 2012). Certainly, gender underlies the assumption that retirement migrants might want to be free of family obligations, since across contexts grandmothers provide more hands-on-care and kin-keeping than do grandfathers (Attias-Donfut 2008; Timonen and Arber 2012). While grandfathers can and do provide childcare, particularly when they have been widowed or divorced (Tarrant 2018), they more often support their children and grandchildren through economic transfers (Herlofson and Hagestad 2018).

Welfare states uphold and reinforce such gendered expectations. European countries have passed various laws to give women better access to paid work, including benefits such as childcare (Letablier 2009). However, such legislation has had limited and uneven effects on the gender division of labour, and women are still primarily responsible for domestic labour, even when they are employed (Damon 2008; Fagnani 2001; Letablier 2009). Thus, when women work for pay, and cannot access public childcare facilities, grandparental caregiving comprises one important dimension of intergenerational support (Attias-Donfut 2008; Glaser et al. 2018; Herlofson and Hagestad 2018; Timonen and Arber 2012). The levels of policy support for childcare and promotion of women's work influence the levels of grandparenting needed (Bordone et al. 2017; Saraceno and Keck 2010). And the more that nation-states rely on families to care for children, the more gendered is this grandparental expectation (Saraceno and Keck 2010). Finally, as some scholars argue, grandparental support is part of the new social contract that has emerged in the context of an ageing population and longer life expectancy (Walker 1996). 
This form of retirement migration challenges the expectations about intergenerational support of both family members and government policy-makers. Obviously, retirement migrants do not engage in the daily or even frequent care of their grandchildren. This then raises the question of what kind of intergenerational grandparenting support do Swiss and British retirement migrants provide? Earlier research on transnational grandparenting has generally found that such support continues, albeit differently. Do retirement migrants seek to free themselves from giving grandparental support, or is it reshaped? While scholars have discussed the impact of distance on grandparenting, relatively little is known about how this influences transnational grandparenting among retirement migrants. According to Timonen and Arber (2012), distance affects both the frequency of contact and emotional bonds. However, it also brings the question of the quantity versus the quality of the interaction into the equation. New forms of contact based on advances in global technology, such as Skype, can imply a different kind of quantity; at the same time, frequency does not necessarily imply quality. Scant research has taken up the question of the extent to which transnational grandparental bonds are maintained when grandparents choose to move to a new country after retirement. Finally, in addressing these questions, we ask to what extent does gender shape grandparenting among retirement migrants?

\section{Methods}

Our study explores retirement migrants from fairly wealthy European countries who move to Spain. The data were collected between August 2016 and March 2017 in two areas of Spain, both popular destinations for retirees from EU countries (Pérez and Medina 2004; Zasada et al. 2010: 126). The larger study explored the relationship between economic resources and migration experiences, the results of which have been discussed elsewhere (Repetti et al. 2018) and issues of intergenerational support in a retirement context. The focus of our research started from the moment people made their decision to move - a process that might last months or even years, but that became concrete at a certain point - and ended with the interview.

We conducted qualitative, in-depth interviews with 27 retirement migrants (see Table 1). The interviews, which lasted between 60 and 90 minutes, were conducted in the interviewees' mother tongue and later transcribed into English. Some 16 of them were undertaken individually and five with couples. In the latter cases, both participants were interviewed at the same time. The ages of the 9 men and 18 women ranged from 56 to 83 years old (mean $=67$ years). Although they came from different European countries, most $(21)$ were from either the UK $(\mathrm{N}=12)$ or Switzerland $(\mathrm{N}=9)$. The grounds for selection were that they had children and grandchildren. Some 26 were living in Spain all year round and no longer had a house in their home country. One, however, Georgette aged 65 from Switzerland, spent several months of the year with her partner in Spain and the rest of her time in an apartment she shared with her elderly mother in her home country. While her situation differs on that point from the other interviewees, her transnational arrangements as a grandmother were similar to the others in this study. 
Table 1: Sample by demographics

\begin{tabular}{|c|c|c|c|c|c|}
\hline $\begin{array}{l}\text { Interviewees } \\
\mathbf{N}=\mathbf{2 7}\end{array}$ & Gender & Age & Partnership Status & $\begin{array}{l}\text { Home } \\
\text { country }\end{array}$ & $\begin{array}{c}\text { Years spent } \\
\text { in Spain }\end{array}$ \\
\hline Nina & $\mathrm{F}$ & 63 & Partnered & UK & 8 \\
\hline Sylvie & $\mathrm{F}$ & 64 & Partnered & UK & 11 \\
\hline Alma & $\mathrm{F}$ & 69 & Partnered with Ivan & UK & 1 \\
\hline Ivan & M & 63 & Partnered with Alma & UK & 1 \\
\hline Bernadette & $\mathrm{F}$ & 59 & Partnered & UK & $15^{*}$ \\
\hline Jane & $\mathrm{F}$ & 63 & Partnered & UK & 3 \\
\hline Ismael & M & 76 & Partnered & UK & 17 \\
\hline Jim & M & 75 & Partnered & UK & 15 \\
\hline Nora & $\mathrm{F}$ & 72 & Single & UK & 12 \\
\hline Claire & $\mathrm{F}$ & 60 & Single & UK & 5 \\
\hline Christiane & $\mathrm{F}$ & 63 & Single & UK & 3 \\
\hline Patricia & $\mathrm{F}$ & 70 & Partnered & UK & 12 \\
\hline Georgette & $\mathrm{F}$ & 65 & Partnered & Switzerland & 1 \\
\hline Juliette & $\mathrm{F}$ & 58 & Partnered with Max & Switzerland & 4 \\
\hline Max & M & 56 & Partnered with Juliette & Germany & 4 \\
\hline Irene & $\mathrm{F}$ & 58 & Partnered with Don & Switzerland & 1 \\
\hline Don & M & 66 & Partnered with Irene & Switzerland & 1 \\
\hline Douglas & M & 76 & Partnered & Switzerland & 19 \\
\hline Pauline & $\mathrm{F}$ & 83 & Single & Switzerland & $38^{\dagger}$ \\
\hline Raoul & M & 73 & Partnered & Switzerland & 10 \\
\hline Jean-Charles & M & 70 & Partnered with Marlyse & Switzerland & 10 \\
\hline Marlyse & $\mathrm{F}$ & 63 & Partnered with Jean-Charles & Switzerland & 10 \\
\hline Charles & M & 70 & Partnered with Michèle & France & 4 \\
\hline Michèle & $\mathrm{F}$ & 71 & Partnered with Charles & Belgium & 4 \\
\hline Violette & $\mathrm{F}$ & 72 & Single & Belgium & 20 \\
\hline Julia & $\mathrm{F}$ & 60 & Partnered & France & 3 \\
\hline Pascale & $\mathrm{F}$ & 64 & Single & France & 1 \\
\hline
\end{tabular}

* Bernadette had arrived with her older husband after he had retired.

$\dagger$ Pauline had arrived with her older husband after he had retired. She is now widowed.

The sample is homogeneous in terms of the types of places in which the interviewees lived - two Spanish retirement communities. As mentioned elsewhere (Repetti 2018), our participants had limited resources and had moved to Spain to maintain or improve their standard of living. Six individuals, faced with labour market insecurities, had taken early retirement and subsequently moved to Spain. Others retired when they were eligible for their state and private pensions, moving to Spain to deal with the economic risks they faced in their home country (Repetti 2018). All had grandchildren - 26 in the country they had left behind and 2 in a third country - 
ranging in age from newborn to young adult; in cases where grandchildren were yet to be born, their potential role as grandparents had been considered explicitly. They had been living in Spain as retirees for varying amounts of time, but all for at least one year, with a median of five years.

In the semi-structured interviews, participants discussed their migration within the larger context of their lives. Goodson and Grzymala-Kazlowska (2017: 9) argue that this is a useful way of studying them because their 'experiences are unique and difficult to access via conventional research and documentary resources'. Apropos family support, the interview focused on the kinds of relationships that participants had with their kin, if and how they communicated with them, whether they saw them, how frequently, for what reasons, where, and the like. Children's reactions after the participants had told them of their decision to move were also discussed. We used a qualitative software program (HyperRESEARCH) to conduct a sociological discourse analysis (Ruiz Ruiz 2009) of the data to elaborate a set of themes and identify issues related to transnational family support, particularly grandparenting.

\section{Providing transnational grandparental support}

Overall, our results suggest that, contrary to assumptions about baby boomers' desire for freedom and individualism, our retirement migrants provide grandparental support transnationally, whether on a regular, irregular, or in times of need basis. Such support can take place in Spain, in the children's country (generally the respondent's own home country), or at a distance (for example through Skype). However, such grandparenting differs from that which occurs with other forms of migration.

In terms of the migration itself, we found that both male and female participants chose their new residence with such support in mind and, in terms of hands-on care, women were particularly involved. That such support was expected was evident in some children's responses to the announcements of their parents' plan to move; participants noted that their decision had sometimes led to conflicts, particularly between the female participants and their daughters, stepdaughters and daughters-in-law.

Planning to facilitate transnational family support emerged as an important issue among our permanently resident participants, one that shaped their decision to migrate as well as their life in Spain. Their considerations included not only the ability to provide childcare, but also keeping in touch and providing economic support, which they felt that their migration actually enhanced.

\section{Accessible locations, spacious housing}

The desire to provide transnational support to their children and grandchildren shaped the interviewees' decision about where to migrate, for they felt it important to remain quickly and easily available for their offspring. This was an often-cited reason for deciding to live in Spain rather than in a more distant country such as Thailand. While living in Spain, they felt that they could still provide support through concrete actions, such as caring for their grandchildren, a consideration that the availability of low-cost airfares and the relative limited distances that they had to travel to reach their family 
enhanced. This is illustrated by $\operatorname{Jim}(75, \mathrm{UK})^{1}$ about why he chose Spain as his destination country. Explaining that he and his wife visited their children and grandchildren in the UK every seven weeks, he noted that 'the most important thing is, I can get on the plane ... EasyJet, Ryan Air, British Airways, and be with my kids, be with my family in a couple of hours.'

All interviewees could access two international airports within an hour's drive, which they regularly mentioned as something that enabled them to join their children and grandchildren quickly, and vice versa. Such availability was also considered vital in the case of an emergency, as Ismael $(76, \mathrm{UK})$ says: 'there have been emergencies, but it's not very difficult to get on an airplane, you know. If you can't get on in Alicante, you can go to Valencia.'

The ability to join children and grandchildren by car 'if necessary' (Jane, 63, UK) was also mentioned, though this was considered less convenient than by plane. For instance, Don (66, Switzerland) mentioned the importance of their proximity to Switzerland and the availability of cheap flights in their decision to move to Spain. When his partner, Irene (58, Switzerland) reminded him that it was also possible to travel by car, he agreed that 'that was also a factor in the choice of location'.

For Jane $(63, \mathrm{UK})$, being able to join her children and grandchildren quickly was not only a reason to choose Spain but also the specific region in which she lived, even though she would have preferred somewhere with a smaller expatriate population: 'we would prefer to be somewhere a little bit more ... Spanish, um, because we pretty much speak the language, um, but then ... it's very good for airports, two airports to go back to the UK ... because our son and our granddaughters are in the UK.'

The wish to provide grandparental support also shaped the participants' choice of housing in terms of both type of home and how they organized it. They mentioned their wish to use any financial advantages they gained from migrating to offer their children and grandchildren space that the latter could not afford in their own living situations. For instance, Irene and Don mentioned wanting to offer their son and daughter-in-law comfortable and relaxing accommodation while they cared for their grandchildren. As Irene (58, Switzerland) explained:

We have a totally independent room at the bottom of the house; it was also our choice to have this for the children. ... When our son, his wife and their baby came last summer, they slept better in our house than at their home. They have a pretty difficult situation in Switzerland, where they live. They each have a studio; for economic reasons, they can't find an apartment, it's pretty complicated. So, when they came here, they were happy to be able to sleep, to have nights when they slept!

Irene and Don explained how their son had been experiencing economic difficulties after just having had a baby. They found it particularly important to be able to welcome him and his family, care for the baby, and offer them space, comfort and calm.

As the above quotes illustrate, although they moved away from their children and grandchildren, our respondents sought a location and housing that enabled them to 
support them. Some also noted an improvement in their relationships with their children and grandchildren because of their migration. They felt that, thanks to the distance, the time they spent together was closer because everyone tried harder and had nothing else to do. They thought this would be less likely if they lived close to their children and grandchildren, when they would merely come and go. Douglas (76, Switzerland) illustrates this view:

Here, when you are three weeks together, day and night, with crying, laughing, ... whereas in Switzerland, maybe we saw them once every two weeks because they didn't have time. So, you see them for an evening, my wife also kept the grandchildren when needed, but it was very random, very short. We have a lot more of our kids here.

Retirement migration also helps our participants give their children and grandchildren more economic and material support. For instance, Jane (63, UK) mentioned that she and her husband had bought a bed for their daughter's home so that they could go and stay with her and her newborn baby. Similarly, Douglas (76, Switzerland) and his wife have a limited retirement pension that makes it hard for them to live in Switzerland. In Spain, though, they can live comfortably on less money, which allows them to provide financial help to their son and his family who are struggling financially. As Douglas explained, 'sometimes, my son calls me and asks: "Dad, could you lend me 300 francs?" ... And each time we go to Switzerland, I invite him and his family [and] we go and eat in a restaurant.'

Contrary to what might be assumed about family solidarity, retirement migration can reshape family relations, and not necessarily in a negative way. Moving away from family reduces the frequency of face-to-face interaction, which may or may not be considered desirable. At the same time, migration in retirement can actually facilitate support and family bonds in a manner that respondents regard as positive.

Finally, as other studies of transnational family practices show, retirement migrants use new communication technologies to interact with their children and grandchildren, maintain family ties and provide emotional support. As Jim (75, UK) explains, '[my wife and I] speak [to our children] every day. Every day my son phones me, my daughter phones me, my granddaughter now phones me. We love being together... With my children, we are very close, we speak every day, we FaceTime every week, ... it's a close family.' However, these alterations in family ties do not necessarily come easily. Retirement migration is a disruption, not least to grandparenting expectations. Thus, as we discuss below, some of our interviewees reported conflicts related to intergenerational support, which emerged when they decided to move.

\section{Grandparental expectations and conflicts with children}

In discussing their children's reactions on learning of their parents' decision to migrate, some reported clashes over expectations related to intergenerational support. Their children had anticipated that they would live in close by and so be able to care 
for their grandchildren on a regular basis. The issue of 'who would care for the grandchildren' when mothers were unable to do so emerged. For instance, the Swiss couple, Irene (58) and Don (66) brought this up in their interview. Don said that 'our children tried to make us feel guilty, [by asking us] what we were going to do for the grandchildren.' Irene clarified that only her daughter had tried to make them feel guilty. Referring to other Swiss migrants who had had similar experiences, she noted that she had heard that 'there are others who have abandoned their children' [laughs].

Douglas (76, Switzerland) mentions the same kind of conflict. 'Our daughter-inlaw wasn't very happy, but [this was] because she simply wanted us to look after the children for her own good. ... From time to time my wife would babysit the children, about once a week [whereas] my son's in-laws practically never looked after the children.' As a result, after he and his wife moved to Spain, their daughter-in-law continued to vent her unhappiness about their decision. 'She always sends out a little jab ... when we talk about it. [Even though they are older now] when we talk about it, she always goes back to it.'

Other interviewees mentioned similar conflicts over expectations surrounding grandparenting. Charles (70) and Michèle (71) lived in Belgium before moving and their children still live there. Charles said, 'there's always a little problem when grandparents leave to live in another country. The children feel like they might be abandoned.' Michèle shared this view and explained further:

They consider that the grandparents go away and then the children are left with the kids. My daughter-in-law told me I was not allowed to leave. I said 'sorry?' 'No', she said, 'now what do we do?' And I said 'well, you live, you learn [how to care for your children without us], that's all.

Julia (60, France) mentioned a similar situation:

On our daughter's side, it went pretty well by saying 'oh yes, I understand you, we're not going to see each other easily, but good.' On the son's side, he was calm. On the other hand, on the daughter-in-law's side, it went extremely badly, with enormous hostility, saying: 'Yes, you won't be there when we have children, you only think of yourself.' At the end of the discussion, she was extremely aggressive verbally. ... In the year that followed, she would barely give us news.

These quotes show the extent to which grandparents, particularly grandmothers, are accused of abandoning their role as caregivers. Some children, especially daughters and daughters-in-law, express unhappiness over not having grandmothers to rely on. Sons, sons-in-law, and grandfathers did not seem to get involved in conflicts over family care; given the gender division of labour, this is not surprising as they generally are not affected. The grandmothers' responses made it clear that although they were willing to provide support, they also resisted being available for childcare full-time, and this created tensions with their daughters and daughters-in-law. 


\section{Caring for grandchildren}

In addition to providing space and material support, all our participants discussed the arrangements they made to provide grandparental support; national childcare policies and school schedules shaped these plans. Interviewees regularly mentioned looking after their grandchildren during school holidays, often for several weeks at a time. Grandparents travelled to their home countries to engage in such care; conversely, some grandchildren joined their grandparents in Spain. For instance, Jim $(75, \mathrm{UK})$ and his wife go to the UK 'during the school holidays, when our granddaughter will be home, that's when we go'. He explained that during their stay, he and his wife took care of their granddaughter while her parents were at work.

Douglas (76, Switzerland) also received his grandchildren during school holidays: 'my kids always used to come here. My children with grandchildren, they would come for three weeks, every year, two to three weeks. ... From time to time my daughter-inlaw also came, with the children, because my son had to work. And [we] took care of the children.' So too did Violette (72, France): 'my ... grandchildren have been here two months a year [during summer holidays] since birth [and] without the parents.'

Another typical time when interviewees provide support is for the birth of a new baby. As Ismael $(76, \mathrm{UK})$ noted, 'well, obviously, we flew to the UK for the birth of both our grandchildren. ... It was expected of course.' Nina (63, UK) also discussed the times that she and her husband flew to the UK to meet a newborn grandchild.

When our granddaughter was born, we went to stay [with my son and his family] for five weeks in April, and then I went for two weeks in July. ... We went to help them ... to support them while they got used to having the baby. We looked after the baby, walked the dogs, cooked the meals, did the washing, we went on holiday with them to the sea. ... We lived with them, which was great.

Such help was especially likely if the arrival of a baby coincided with another issue (health, economic or social problems) as the next two quotes illustrate. We begin with Jane (63, UK): 'when my daughter-in-law had the second one, she had sepsis and so she was rushed to the hospital. It was very difficult for them to manage so I went over to help out.' Similarly, Georgette's ( 65 , Switzerland) daughter had recently had a baby, and faced difficult times with the baby's father, which made it harder for her to deal with the new situation. Since then, Georgette found it important to be able to provide some help to her daughter by welcoming her and the baby in Spain. She said:

My daughter comes on vacation regularly. Last year [after the baby's birth] she came twice, for one week each time, which allowed her to take off a little bit, and I was able to be with her and her little girl 24 hours a day and it was great, it was practical for her.

Our data suggest that grandparents arrange to provide care transnationally when the parents need help. This can be in particular contexts - such as when a parent is ill and 
there is a newborn baby in the house. It is also often for situations where state policy provisions are scarce, such as during school holidays or in the first years after the birth of a child. This suggests that although they live away from their children and grandchildren, these retirement migrants remain an important caregiving resource.

\section{Gender and transnational grandparental support}

Both men and women spoke of needing to offer grandparental support and of how their family relationships shaped their migratory decision and organized their lives in Spain. They also both mentioned providing material and economic support. Yet, in expected ways, gender differences still emerged in relation to exactly what grandparental support entailed. We found that women travelled more often than their partners for grandparenting reasons and saw it as their duty to deliver such support. This sense of obligation was based on affective bonds that the men also expressed. However, the different expectations of care from grandmothers and grandfathers go back to the gender division of labour, as Jane's $(63, \mathrm{UK})$ comments illustrate. She flies regularly to see her children and grandchildren while her husband 'would stay [in Spain] and play golf'. While they regularly visit their grandchildren together in the UK, her husband flies less frequently; she thought it was because he felt less committed to maintaining kinship ties with their children and grandchildren and she attributed this to natural gender differences: 'I think a mother probably just goes more often, it's just, it's different isn't it, the relationship?' Also, when they spend time in the UK together, their activities are split. Jane provides most of the care to the grandchildren - who are still young - while her husband spends more time on leisure activities: 'but my husband would go off and he'd probably go practice some golf. ... [He] likes to go shopping so sometimes he would go shopping, he would take the dog for a walk. I would take the children to the park to play.' When pressed for more details about how Jane and her husband provide care in this context, she said, 'both of us [provide care] I would say, but things like nappy changing I would do. You can imagine! Huh, the feeding aspects, the nurturing things, always fall to the woman doesn't it? Or it usually falls to the woman.' She saw this gender division of labour as natural.

Nina (63, UK) described a similar situation when she and her husband visit their children and grandchildren. Like Jane, she provides most of the childcare while her husband spends time in other activities. She also understands these differences as a natural tendency of men and women to be unequally involved in care work:

[When] my husband and I went to help our children, because the baby was just born ... I cared for the baby; we did the shopping together. He did some artwork, and generally got quite bored, because his life was very domestic, he's not used to that. ... I think he got tired at the end. [Because] apart from looking after the baby, there was nothing to do. So I think he got a little bit bored with not having his own routine, his own life. ... And for him it's more difficult than it is to me. Because I get the emotional satisfaction of being with my family, I think that is like a difference for the way men are constructed. 
Nina notes that her husband does feed, wash and change the baby, but does not particularly enjoy it. 'Well, he doesn't mind, but he doesn't think it's the most exciting thing. It's not as exciting as playing golf.' In fact, she returned to help her children after that, but without her husband.

Thus, while both male and female participants want to support their children and grandchildren and organize their lives in Spain to enable this, women are more involved in the hands-on-care work that childrearing entails. As the discussion on conflicts makes clear, they are the ones expected to provide care, but they also wish to provide care and consider is their natural duty as grandmothers.

\section{Discussion}

On the face of it, the form of retirement migration we study here - a situation in which retirees take up permanent residence in a new country - challenges expectations concerning grandparental support. Unlike older people who migrate to join their families in a new country, these retirement migrants leave their families behind. Some scholars have depicted such movement as a kind of lifestyle migration in which retirees seek sunshine and freedom from family obligations.

In this context, we examined a group of retirement migrants who moved to Spain to enhance their quality of life by relocating to a place where the cost of living was lower. We asked to what extent grandparental support influenced their migration. Were they aware that they were expected to provide care to grandchildren, and were they seeking to flee such family obligations? Further, as Arber and Timonen (2012; Timonen Arber 2012) urge, we explored the extent to which gender shapes the answers to these questions.

Our findings conclude that such questions are too simplistic and inadequately address the complexity of transnational family forms, especially insofar as they relate to proximity and family relationships. Certainly, our participants understood that their children might expect them to help care for grandchildren; some reported that their decision to migrate had created conflicts, especially between female migrants and the daughters, step-daughters and daughters-in-law they had left behind. While they resisted the idea that their families should rely on them for full-time childcare, they were also clear that they had based their decision to relocate on maintaining family ties and providing support. They chose Spain, and that region in Spain, explicitly because of the easily accessible and cheap transport available between their home countries and their new one. In this way, they could easily arrange to provide care, either on a regular basis, as in school holidays, or in the event of an emergency.

Their migration decisions also cast light on another important dimension that might otherwise be overlooked. This is that, in moving to a more affordable region in a Southern European country, they would not only gain more economic security for themselves, but they would also be able to provide both financial support and a haven of sorts for their families. Countering the assumption that proximity fosters more frequent contact, these migrants felt that they could offer their children and grandchildren a place for holidays and relaxation, and thus plenty of time together to build 
close relationships. While distance clearly affects people's relationships with their children and grandchildren, there are positive aspects to it, both because new technologies make communication easy and because they spent more quality time with their children and grandchildren when they are together. Thus, the question of transnational grandparental relationships is more complex than is sometimes portrayed.

That said, gender relations in terms of family support appear durable across distance, and among our sample, the women performed the majority of childcare while men either helped or supported their grandchildren in other ways. Although both grandparents respond to need, the frequency of care and types of activities vary. Women provide more frequent, regular, hands-on personal care than men. However, an understanding of gender might lead us to frame the issue of fleeing family obligations a bit differently. Some scholars have argued that Europeans who retire to poorer countries wish to escape family obligations, and that this is particular to the baby-boom generation (Ahmed 2015; Gilleard and Higgs 2005; Oliver 2008). Our study suggests that a more nuanced view is needed. The scholarly discussion on retirement migration attributes the shift in women's responses to demands for care to baby-boom culture rather than seeing it as a reaction to gender inequality. The women in our sample clearly understood that they were expected to engage in childcare, and some resisted it. From their comments, it is clear that grandfathers do help to care for grandchildren, but also find time to engage in leisure pursuits such as golf. The research shows that women in retirement continue to feel obliged to engage in domestic labour, while men are freer to enjoy their hobbies or other non-work activities (Repetti et al. 2018).

Thus, what our data suggest is that these grandparents did not seek to stop supporting their grandchildren, but rather, on the part of the grandmothers, to reduce and limit their labour obligations and, in the case of both grandparents, to gain more economic security. Facio (1996) found that grandmothers who live close to their grandchildren adopt various strategies to resist their childcare obligations and gain some independence and freedom. Although grandmothers may enjoy caring for their grandchildren, they also find it confining and this resistance is not unique to baby boomers. Among our sample, grandparenting and family relationships were still important, and both men and women wanted to help their offspring. The removal of the expectation of full-time care that distance creates may serve to enhance relationships and increase the grandparents' ability to provide other forms of help. In other words, it may give them a better sense of control over the intensity and forms of grandparental support.

In sum, our research shows that there are several reasons why retirement migrants with limited resources move to Southern Europe. By relocating in a country with a lower cost of living, they have a larger range of choices than in their home country over how to organize their life (Repetti et al. 2018). In so doing, they may evade family obligations to a certain extent, but at the same time, their increased options allow them to maintain family support. Like migrants in general, as well as other elderly migrants (Ciobanu et al. 2017), they continue to support their families across distances, but they do so differently.

Although our Spanish case study of retirement migrants in Europe challenges certain established views on grandparental support, it is obviously limited in scope and 
cannot be generalized. More comparative qualitative and quantitative data would give us a better understanding of the variety of contexts that retirement migration affects. For example, do the regions of the world that migrants select for their retirement determine whether they are more, less or differently involved in offering grandparental support? In addition, we failed to elicit detailed information on the numbers of grandchildren involved, how many were born prior to migration, their ages, or the extent to which the retirement migrants had provided care to them (and what kind) prior to migration. Therefore, assessing change in such care is not possible here. Although we did not ask our participants to report conflict with their children, the frequency with which such conflicts emerged, especially in relation to gendered expectations concerning childcare, was nonetheless notable.

\section{Acknowledgements}

The authors thank the Swiss National Science Foundation for financing this research.

\section{Note}

1. To ensure anonymity, all names have been changed. The country specified (UK, Switzerland, and so on) is where the respondent spent the main part of his or her life and from where most of the retirement income derives.

\section{References}

Ahmed, A. (2015) Retiring to Spain: women's narratives of nostalgia, belonging and community, Bristol: Policy Press.

Albertini, M., D. Mantovani and G. Gasperoni (2018) 'Intergenerational relations among immigrants in Europe: the role of ethnic differences, migration and acculturation', Journal of Ethnic and Migration Studies, online early, 1-14, doi: 10.1080/1369183X.2018.1485202.

Arber, S. and V. Timonen (2012) 'Grandparenting in the 21st century: new directions', in S. Arber and V. Timonen (eds) Contemporary grandparenting: changing family relationships in global contexts, Bristol: Policy Press, 247-64.

Attias-Donfut, C. (2008) 'Les grands-parents en Europe: de nouveaux soutiens de famille', Informations sociales, 149 (5), 54-67, available at: www.cairn.info/revue-informationssociales-2008-5-page-54.htm.

Baldassar, L. and L. Merla (2013) Transnational families, migration and the circulation of care: understanding mobility and absence in family life, New York: Routledge.

Baldassar, L., C. Vellekoop Baldock and R. Wilding (2007) Families caring across borders: migration, ageing and transnational caregiving, Houndmills, Basingstoke: Palgrave Macmillan.

Bastia, T. (2009) 'Women's migration and the crisis of care: grandmothers caring for grandchildren in urban Bolivia', Gender and Development, 17 (3), 389-401, doi: 10.1080/13552070903298378.

Baykara-Krumme, H. and T. Fokkema (2018) 'The impact of migration on intergenerational solidarity types', Journal of Ethnic and Migration Studies, online early, 1-21, doi: 10.1080/1369183X.2018.1485203.

Benson, M. and K. O'Reilly (2009) 'Migration and the search for a better way of life: a critical exploration of lifestyle migration', The Sociological Review, 57 (4), 68-625, doi: 10.1111/j.1467-954X.2009.01864.x.

Bordone, V. and H. de Valk (2016) 'Intergenerational support among migrant families in Europe', European Journal of Ageing, 13 (3), 259-70, doi: 10.1007/s10433-016-0363-6. 
Bordone, V., B. Arpino and A. Aassve (2017) 'Patterns of grandparental childcare across Europe: the role of the policy context and working mothers' need', Ageing and Society, 37 (4), 845-73, doi: 10.1017/S0144686X1600009X.

Castles, S., H. de Haas and M. J. Miller (2014) The age of migration, Houndmills, Basingstoke: Palgrave Macmillan.

Ciobanu, R. O., T. Fokkema and M. Nedelcu (2017) 'Ageing as a migrant: vulnerabilities, agency and policy implications', Journal of Ethnic and Migration Studies, 47 (2), 164-81, doi: 10.1080/1369183X.2016.1238903.

Da, W. (2003) 'Transnational grandparenting: child care arrangements among migrants from the People's Republic of China to Australia', Journal of International Migration and Integration, 4 (1), 79-103, doi: 10.1007/s12134-003-1020-4.

Damon, J. (2008) 'Les politiques familiales dans l'union européenne: une convergence croissante', Recherches familiales, 1 (5), 33-53, doi: 10.3917/rf.005.0033.

Ducu, V. (2018) Romanian transnational families, Houndmills, Basingstoke: Palgrave Macmillan.

Facio, E. (1996) Understanding older Chicanas: sociological and policy perspectives, Thousand Oaks, CA: Sage, doi: 10.4135/9781483327013.

Fagnani, J. (2001) 'La politique d'accueil de la petite enfance en France: ombres et lumières', Travail, genre et sociétés, 2 (6), 105-19, doi: 10.3917/tgs.006.0105.

Gehring, A. (2017) 'Pensioners on the move: a "legal gate" perspective on retirement migration to Spain', Population, Space and Place, 23 (5), 1-11, doi: 10.1002/psp.2007.

Gilleard, C. and P. Higgs (2005) Contexts of ageing: class, cohort and community, Cambridge: Polity Press.

Glaser, K., R. Stuchbury, D. Price, G. Di Gessa, E. Ribe and A. Tinker (2018) 'Trends in the prevalence of grandparents living with grandchild(ren) in selected European countries and the United States', European Journal of Ageing, 15 (3), 237-50, doi: 10.1007/s10433-0180474-3.

Goodson, L. and A. Grzymala-Kazlowska (2017) 'Researching migration in a superdiverse society: challenges, methods, concerns and promises', Sociological Research Online, 22 (1), 1-13, doi: $10.5153 /$ sro.4168.

Hayes, M. (2015) 'Moving south: the economic motives and structural context of North America's emigrants in Cuenca, Ecuador', Mobilities, 10 (2), 267-84, doi: 10.1080/ 17450101.2013.858940.

Herlofson, K., and G. O. Hagestad (2018) 'Transformations in the role of grandparents across welfare states', in S. Arber and V. Timonen (eds) Contemporary grandparenting: changing family relationships in global contexts, Bristol: Policy Press, 28-50.

Holmes, M. (2010) 'Intimacy, distance relationships and emotional care', Recherches sociologiques et anthropologiques, 41 (1), 105-23, doi: 10.4000/rsa.191.

Huete, R., A. Mantecón and J. Estévez (2013) 'Challenges of lifestyle migration research: reflections and findings about the Spanish crisis', Mobilities, 8 (3), 331-48, doi: 10.1080/17450101.2013.814236.

Izuhara, M. (2010) Ageing and intergenerational relations: family reciprocity from a global perspective. Bristol: Policy Press.

King, R. and A. Lulle (2016) 'Grandmothers migrating, working and caring: Latvian women between survival and self-realisation', Population Horizons, 13 (2), 43-53, doi: 10.1515/ pophzn-2016-0003.

King, R., A. M. Warnes and A. Williams (1998) 'International retirement migration in Europe', International Journal of Population Geography, 4 (2), 91-111, doi: 10.1002/(SICI)10991220(199806)4:2<91::AID-IJPG97>3.0.CO;2-S.

King, R., E. Cela, T. Fokkema and J. Vullnetari (2014) 'The migration and well-being of the zero generation: transgenerational care, grandparenting, and loneliness amongst Albanian older people', Population, Space and Place, 20 (8), 728-38, doi: 10.1002/psp.1895. 


\section{Marion Repetti and Toni Calasanti}

Letablier, M.-T. (2009) 'Régimes d'état-providence et conventions de genre en Europe', Informations sociales, 1 (151), 102-9, available at: www.cairn.info/revue-informationssociales-2009-1-page-102.htm.

Longino, C. F. and V. W. Marshall (1990) 'North American research on seasonal migration', Ageing \& Society, 10 (2), 229-35, doi: 10.1017/S0144686X00008096.

Mazzucato, V. and D. Schans (2011) 'Transnational families and the well-being of children: conceptual and methodological challenges', Journal of Marriage and Family, 73 (4), 704-12, doi: 10.1111/j.1741-3737.2011.00840.x.

Nedelcu, M. (2009) 'La "génération zéro": du sédentaire à l'acteur circulant. Effets de mobilité sur la génération des parents des migrants roumains hautement qualifiés à Toronto', in G. Cortès, and L. Faret (eds) Les circulations transnationales: lire les turbulences migratoires contemporaines, Paris: Armand Colin, 187-9.

Nedelcu, M. (2017) 'Transnational grandparenting in the digital age: mediated co-presence and childcare in the case of Romanian migrants in Switzerland and Canada', European Journal of Ageing, 14 (4), 375-83, doi: 10.1007/s10433-017-0436-1.

Nedelcu, M. and M. Wyss (2016) “"Doing family” through ICT-mediated ordinary co-presence: transnational communication practices of Romanian migrants in Switzerland', Global Networks, 16 (2), 202-18, doi: 10.1111/glob.12110.

Oliver, C. (2008) Retirement migration: paradoxes of ageing, New York: Routledge.

Pérez, J. M. and J. S. Medina (2004) 'Territoire et immigration en Espagne: une étude de cas en Palma de Mallorca et León', Espace, Société, Territoire, 274, doi: 10.4000/cybergeo.2440.

Purkayastha, B., M. Iwata, S. M. Adur, A. Ray and T. Tiamzon (2012) As the leaves turn gold, London: Rowman \& Littlefield.

Repetti, M., C. Phillipson and T. Calasanti (2018) 'Retirement migration in Europe: a choice for a better life?', Sociological Research Online, 23 (4), 780-794, doi: 10.1177/13607804 18782243.

Ruiz Ruiz, J. (2009) 'Sociological discourse analysis: methods and logic', Forum Qualitative Social Research, 10 (2), article 26, doi: 10.17169/fqs-10.2.1298.

Saraceno, C. and W. Keck (2010) 'Can we identify intergenerational policy regimes in Europe?', European Societies, 12 (5), 675-96, doi: 10.1080/14616696.2010.483006.

Tarrant, A. (2018) 'Grandfathering: the construction of new identities and masculinities', in S. Arber and V. Timonen (eds) Contemporary grandparenting: changing family relationships in global contexts, Bristol: Policy Press, 183-202.

Timonen V. and S. Arber (2012) 'A new look at grandparenting', in S. Arber and V. Timonen (eds) Contemporary grandparenting: changing family relationships in global contexts, Bristol: Policy Press, 1-24.

Torres, S. (2012) 'International migration: patterns and implications for exclusion in old age', in T. Scharf and N. C. Keating (eds) From exclusion to inclusion in old age, Bristol: Policy Press, 33-49.

Walker, A. (1996) The new generational contract, London: UCL Press.

Williams, A. M. and M. C. Hall (2000) 'Tourism and migration: new relationships between production and consumption', Tourism Geographies, 2 (1), 5-27, doi: 10.1080/1461668003 63420 .

Woodspring, N. (2016) Baby boomers: time and ageing bodies, Bristol: Policy Press.

Zasada, I., S. Alves, F. C. Müller, A. Piorr, R. Berges and S. Bell (2010) 'International retirement migration in the Alicante region, Spain: process, spatial pattern and environmental impacts', Journal of Environmental Planning and Management, 53 (1), 125-41, doi: 10.1080/09640560903399905.

Zickgraf, C. (2017) 'Transnational ageing and the "zero generation": the role of Moroccan migrants' parents in care circulation', Journal of Ethnic and Migration Studies, 43 (2), 321-37, doi: 10.1080/1369183X.2016.1238912. 